\title{
The embedded state and social provisioning. Insights from Norbert Elias
}

Bruno Tinel

in Tae-Hee Jo and Zdravka Todorova. Advancing the Frontiers of Heterodox Economics. Essays in honor of Frederic S. Lee, Routledge, pp.265-280, 2015. 〈halshs-01199416〉

\section{Introduction}

Norbert Elias (1897-1990) is one of the giants in the social sciences in the twentiethcentury. His rich contributions are, however, not much discussed by economistsmainstream and heterodox economists alike. It might be because the topics he dealt with seem barely related to the 'economy' as we understand now. Titles like The Loneliness of the Dying or The Court Society appear to be more akin to an analysis of Faulkner or Shakespeare. But Elias has also made some major contributions to topics like individualism, sport, social norms, knowledge, and behavior. The Civilizing Process is probably the core of his works. In 1998, it was listed by the International Sociological Association as the seventh most important book of the twentieth century. ${ }^{1}$ The idea of this book is very ambitious. Elias' plan is to explain the emergence and the structuration of the modern state throughout a very long historical overview that goes from the end of the Carolingian Empire to absolute monarchy in Europe. He considers that the civilizing process involves a deep historical transformation of social habits, including the most trivial ones like everyday life manners, where self-restraint behavior is more and more internalized by individuals with the growth of social differentiation and interconnection. This internalization process is related to the change in the social access to violence which is increasingly centralized and monopolized through the formation and development of the state system. Initially the book was made of two volumes; the first one discusses the historical development of social attitudes and the second volume analyzes the state formation. The latter part is directly related to the concerns of heterodox economics as it focuses on the emergence of the modern state but, strangely enough, such an important book remains overlooked by heterodox economics. ${ }^{2}$ Note that in other disciplines, like medieval history or sociology, Elias' global framework of analysis on the modern state formation is considered as a kind of model. ${ }^{3}$

In mainstream economics, the state is something that exists in order to solve (only partially) market failures. In most of the Keynesian traditions, the state is something that exists in order to lead the economy to full employment. In Marxist economics, the state is something that exists in order to maintain and reproduce the capitalist class as

\footnotetext{
${ }^{1}$ See the Top 10 list here: www.isa-sociology.org/books/books10.htm.

${ }^{2}$ See Elias ([1939] 2000) for any reference and also the HyperElias $\subset$ WorldCatalogue ${ }^{\text {HTM }}$, http://hyperelias.jku.at/.

${ }^{3}$ In France, see for instance Alain Guéry's works in the tradition of the Annales school of Georges Duby and Jacques Le Goff, cf. Descimon and Guéry (2000). On the analytical side of the issue, see the imposing work of Pierre Bourdieu (2012). Check also the website of the Norbert Elias Foundation, www.norberteliasfoundation.nl/.
} 
the dominant class in the society. Nevertheless, it is dubious that the state exists and has been able to perpetuate through centuries only to fulfill a specific and/or such a simple functionalist purpose. One of the important features in Elias' framework is to analyze the modern state formation without resorting to a purposive or deterministic argument. In particular, he shows that the state is not an immutable entity but an evolving set of elements, which are themselves subject to transformations, that exercise altogether a contradictory role in the process of social provisioning and of social (or class) reproduction. The state cannot be understood as an entity situated out of the economy and its development. Neither can it be interpreted as a pure economic entity created to achieve one form of efficiency or another. The aim of this chapter is to present the basic line of argument that Elias develops and to point out some elements that can be of crucial importance for heterodox economics as defined by Frederic Lee in his constructive book, A History of Heterodox Economics, and some other papers.

This chapter should be considered as an engagement with Lee's endeavor to build an integrative and pluralist approach to the social provisioning process. His pioneering work and energetic commitment to heterodox economics contributes to the invaluable bedrock that opens up a range of opportunities to advance heterodox economics. Lee rejects indeed the mainstream explanation of the economy as it considers asocial and ahistorical individuals and uses fictitious concepts based on a deductivist and closedsystem methodology (Lee 2009, 7). Such a dismissal is actually based on a long series of critiques which form together a general structured critique and which Lee considers also as providing a way to do heterodox economics in a very different fashion from mainstream. He defines heterodoxy as being

concerned with explaining the process that provides the flow of goods and services required by society to meet the needs of those who participate in its activities. That is from a heterodox perspective, economics is the science of the social provisioning process. ... The heterodox explanation involves human agency in a cultural context and social processes in historical time affecting resources, consumption patterns, production and reproduction, and the meaning (or ideology) of market, state, and non market/state activities engaged in social provisioning. Thus heterodox economic theory is a theoretical explanation of the historical process of social provisioning within the context of a capitalist economy.

(Lee 2009, 8, emphasis in original)

Lee has developed this view in several recent papers (Lee 2008, 2011a, 2011b, 2011c).

Besides these empirical grounds of the heterodox economic theory, he shows that heterodoxy is a community of economists who contribute to develop approaches such as Austrian economics, feminist economics, Institutional-evolutionary economics, Marxian-radical economics, Post Keynesian and Sraffian economics, and social economics. Lee emphasizes that all of these approaches overlap as heterodox economists do engage most of the time with several traditions and develop integrations and synthesis between them. The outcome of all these crossings, borrowings, and combinations (or "cross-approach engagement") is a pluralistic integrative research program, which is "now an established feature on the disciplinary landscape and the progressive future of economics" (Lee 2008). Lee himself has 
played an important role to make the heterodox community more aware of itself (Jo 2013) and his global argument has been resumed and expanded notably by Jo (2011) and Todorova (2013). Elias is among those forgotten precursors of the heterodox approach in economics as described by Lee, which will be one day or another fully acknowledged as such. He is himself an heir to a long tradition mainly from the sociology and the history of both Max Weber and the German school but a careful reading shows that he had also a solid background in economics. His (socio)economics, as we shall see, was not made of equilibrium, interdependent markets through the price system only and asocial individuals maximizing their utility in an ahistorical context, but rather a historical process combining various mechanisms where individuals are largely constrained by the institutions and the development level of the economic and technological forces they get from the past. His economics has necessarily both a political and a sociological side, and vice versa. These methodological features of Elias' work make of him a genuine forerunner of what Fred Lee later described as heterodoxy. In addition, his work is of some interest for heterodoxy also because just as Marx did with the analysis of the emergence of capitalism, Elias gives insights notably on the emergence of the modern state and, related to it, economic competition and the diffusion of monetary exchanges before the advent of capitalism. His analysis brings light on some major notions that heterodoxy has often to take for granted. He shows how some significant social facts of the capitalist system are not eternal truth but evolving and contingent entities connected one with another through relations changing irreversibly and more or less rapidly.

This conception of social change takes a clear and telling form in the analysis of the process of monopolization. Elias emphasizes the historical link between the monopoly over violence, initially pointed out by Max Weber (1968), and over taxes in the genesis of the modern form of the state, which has important implications for the preconditions of economic activity such as production, exchange, and money. The method looks inductive because Elias is permanently referring to historical facts but he considers this historical case as a general and representative narrative on state formation. He presents a dynamic analysis describing the step by step mechanism that progressively led from feudalism, characterized by an extreme decentralization of society in which numerous warriors were the real rulers, to the emergence of absolutism in Western Europe, characterized by a relatively "stable and centralized government apparatus" (Elias 2000, xii). To Elias, the latter is the first stage of the modern state. The military and social competition mechanism at stake is supposed to apply with more or less accuracy to every nation state and, interestingly, it appears as a metaphor of economic activity: indeed one of his key arguments is that competition leads progressively to monopoly by the successive elimination of competitors. The twin accumulation of military and financial potential, which in the final analysis rests upon the possession of territories, led to the domination of whole continents by modern states.

The remaining chapter is organized as follows. The second section presents the basic principles of competition associated with the monopolization mechanism which implies a 'no tax, no state' rule discussed in the third section. The fourth section presents the intuition that the administration is the result of reciprocal dependence. The fifth section examines the relation between taxes and money. The sixth section addresses the mutual effects of centralization and economic development. The final section concludes. 


\section{A movement of monopolization: eat or get eaten}

In the feudal system, after the fragmentation of the Carolingian Empire which occurred progressively during the ninth century, any territory (a dukedom for example) would include several warrior families which enjoyed the privilege to use arms and to possess land. The House which dominated a territory was also the richest as it possessed the vastest landed estate. Its domination disappeared if it did not succeed in militarily outclassing the other warrior families on this given territory. Military domination of a feudal lord was grounded on property income and on the number of his vassals and feudatories installed in its territory. ${ }^{4}$ As soon as predominance of a House was ensured in the limits of its domain a new struggle for hegemony started over a larger area. This mechanism gives us one of the most fundamental keys to explain the struggle of the great lords to control the Kingdom as a whole. The unification movement among several distinct seigneuries occurred in the same way that led to the domination of a knight or a feudal lord over and inside a given territory. This process of progressive concentration and centralization of military and political power unfolded during the five centuries constituting the second part of the middle ages in the big countries of Western Europe and led to the formation of nation states.

In the early phase of the process, small territorial entities of the future state played a very decisive role. Those dominant units were relatively small and relatively loosely structured just like in every place in the world where the division of labor and exchanges (internal as well as external) are not well developed. For Elias, the Dukedom of France at the beginning of the twelfth century is a good example. ${ }^{5}$ He mentions a few feudal seigneuries which also transformed into small Kingdoms, Dukedoms, or Counties in the German Empire; the same process applied also to the Scottish Kingdom before being integrated to the UK along with England and Northern Ireland. Basing his analysis mainly on French medieval history, Elias shows how 'at the beginning' it was not obvious that the House of the Capet would 'in the end' (i.e., three or four centuries later) impose and centralize its domination monopoly over the territory of the West Frankish Kingdom. Capet was one of many lords in this era. As a king, although he enjoyed more spiritual prestige, his effective force was not at all significantly superior to many other lords of his realm; for instance, Louis VI 'the Fat' (1081-1137) was undeniably weaker than his vassal, the Duke of Normandy, who had also been King of England since 1066, 42 years before Louis' coronation in 1108.

No less conscious of their own interest than dominant classes nowadays, medieval lords and knights were spurred towards internal and external expansion for livelihood issues. The forms of competition were imposed on feudal lords, they had to extend their domain through neighbor subjugations in order not to be themselves defeated. Defeat was equivalent to an elimination of the scene of potential competitors by loss of territory and military control or even by physical destruction: they had to grow to avoid declining. The ones who merely wanted to preserve their possessions seriously imperiled themselves by enabling a more bellicose neighbor to absorb them. Such kind of social competition inevitably triggered monopolist mechanisms. At the

\footnotetext{
${ }^{4}$ A feudatory holds an estate in land (fiefdom) granted by a lord to his vassal on the condition of homage and service. A vassal can be the owner of his land.

${ }^{5}$ At this time these possessions represent not much more than Paris and Orléans plus a few small cities around Paris like Senlis.
} 
beginning, a lot of free competitors were present in the arena. Their means of competition were not much different from each others'. After many victories and defeats, only a few competitors were left on the scene. Even though the defeated competitors could still enjoy important social influence they became secondary protagonists. The decisive struggle opposes the last two defeaters who are already close to a monopoly position. Norbert Elias puts these thoughts forward in the following terms:

Precisely because estate owners were in a certain sense opposed to one another, just as states today, the acquisition of new land by one neighbour represented a direct or indirect threat to the others. ... [A]nyone who declines to compete, merely conserving his property while others strive for increase, necessarily ends up 'smaller' and weaker than the others, and is in ever-increasing danger of succumbing to them at the first opportunity.

(Elias 2000, 219)

This observation is important for heterodox economics because it cleverly dismisses the idea of a 'competitive equilibrium.' Indeed, each individual unit involved in a competitive process has to constantly undertake new actions in order to simply try to reproduce its position in the competition. Hence at the individual level, each unit is continually constrained to struggle not to disappear from the scene: "in a society with such competitive pressures, he who does not gain 'more' automatically becomes 'less'" (Elias 2000, 263). Those who are unable to provide enough resources or to timely renew their strategies in order to sustain this competitive process are pushed out. Consequently, more resources and power accrue to some of the remaining competitors. Elias thus argues that there is no competitive equilibrium in this historical process:

If we assume that to begin with all the people in this area fight one other for the available opportunities, the probability that they will maintain this state of equilibrium indefinitely and that no partner will triumph in any of these pairs is extremely small ... and the probability that sooner or later individual contestants will overcome their opponents is extremely high.

(Elias 2000, 269)

Of course the estate of the eliminated competitors were not equally shared among the survivors, since the estate itself was one of the objects of competition. At the social level, the combination of all these individual hectic activities could hardly be named an 'equilibrium.' On the contrary, the combination of these frenetic individual behaviors produced a tumultuous and unpredictable environment for everyone. This competition process that generated constantly and endogenously changing surroundings had only one outcome: the reduction in the number of actual participants and the growth of their power. No doubt such a process of competition was not confined to the political and military spheres:

The mechanism leading to hegemony is always the same. In a similar way- through the accumulation of property - a small number of economic enterprises in more recent times have slowly outstripped their rivals and competed with each other, until finally one or two of them control and dominate a particular branch of the economy as a monopoly. 
$(\text { Elias 2000, 260) })^{6}$

\section{The exclusive control over physical violence and tax imposition}

For Elias, the monopolist position of modern central power is defined by a twofold monopoly: (i) monopoly over military means and (ii) monopoly over tax levying. Those two monopolies go along together and support each other: the financial means accruing to the central power enables it to maintain military and police monopoly, which, in turn, ensures the effectiveness in taxation. Modern societies based on a sophisticated division of labor are also characterized by a permanent administrative apparatus specialized in running both monopolies. Elias considers this twofold monopoly as a key element among the broader set of monopolies, which altogether form the state. If one of the two key monopolies fails then the state starts to decline. The complementarity between military power and tax power has to be emphasized: these two powers are the two sides of the same coin in the hands of the one who rules. Tax is hence a compulsory phenomenon, which is related to the existence of a united ruling entity within a given territory: their relative acceptance is therefore ontologically related to the relative acceptance of the ruler by the rest of the society. In other words, the ability of a central authority to raise taxes on the society determines the ability of this authority to reproduce itself as the central power which could be summed as 'no tax, no state.'

This basic principle can find some possible applications in contemporary economic problems. For example, in advanced capitalist countries, tax reductions induce higher rates of public debts (for a given level of expenditures) which make the state more dependent on financial markets: part of the contemporary sovereign debt 'problems' are due to a weakening of the tax system which eventually undermines the whole state apparatus. Another possible field of application relates to the role of the state in developing countries. The contemporary literature on the 'state failure' is prolific. Issues like development strategy, institutional capacities, and service-delivery tasks are widely treated but very little reflection is actually devoted to the analysis of the twofold monopoly constitution. Very often, one can read papers advocating sophisticated plans for the development and the 'governance' of countries in which the state is so nonexistent that the ruling class is constrained to delegate the levying of taxes like tariffs to private companies. Elias shows that the formation of the state is a precondition to modern economic development, which is too often overlooked by the profession and international organizations. A third possible application of the 'no tax, no state' principle could be named the 'Dutch disease problem' of the state: those developing countries which possess a great quantity of natural resources like petrol, gas, or diamonds for instance are not encouraged to develop a genuine tax system and the state apparatus that is supposed to go with it. The absence of a real state organization is then an incentive for rent seeking strategies like guerillas and mafias to appropriate the natural resources. As a consequence, permanent instability, underdevelopment, and patron/client relations are prevalent.

\footnotetext{
${ }^{6}$ On the general character of the monopoly mechanism and the fact that some would call it a 'law,' see Elias (2000, 264). See also page 269 for a global and synthetic formulation.
} 


\section{Administration as reciprocal dependence}

Elias explains how and why those 'twin' monopolies emerged in West Francia (former western Frankish Empire) a 1,000 years ago during the eleventh century. As already noticed, his starting point corresponds to a situation where each warrior exercises all government functions over the limited piece of land under the warrior's control. A warrior can start a war when he wants to protect or to extend his possessions. Conquest and domination functions over owned land are both reserved to the private initiative of each warrior. The victorious lord increases his potential power by appropriation of at least a part of the military and economic means of the defeated until only one individual concentrates all this potential in his hands. Defeated competitors are eliminated and become dependent on remaining competitors. But this should not be interpreted naively. In fact, dependency develops reciprocally from a certain threshold of concentration onwards, at least in sufficiently differentiated societies. The more the number of individuals who lost their independency increases, the more their collective social power increases to face up to the decreasing number of monopolists.

The social power of dependent people is based on two pillars: (i) the increasing number of dependents and (ii) the monopolist's need of the dependents to maintain and use effectively its monopoly potential. Elias explains that the accumulation of great quantities of land, soldiers, and financial means in a few hands makes their control more difficult. In other words, the monopolist cannot handle his increasing power on his own as it grows. He is constrained to delegate his decision power to specialized people who depend on him. Hence the monopolist progressively becomes embedded in the social network of those who are depending on him because he has to organize his power through a more and more complex network of relations and procedures, which progressively crystallize into an administration:

The more people are made dependent by the monopoly mechanism, the greater becomes the power of the dependent, not only individually but also collectively, in relation to the one or more monopolists. This happens not only because of the small number of those approaching the monopoly position, but because of their own dependence on ever more dependents in preserving and exploiting the power potential they have monopolized.

(Elias 2000, 270)

This process was very slow and lasted over centuries. The development and the concentration of the twin monopolies lead to a differentiation of activities and to an increasing division of labor inside the organizations which are meant to maintain and enforce the monopoly. At one point, those organizations start to have their own weight and their own rules to which the holder of the monopoly has to submit to. The possession of such a monopoly requires establishing a large administration and a well developed division of labor which imply more and more formal rules and procedures for appointment, promotion, and activity fulfillment:

the more comprehensive a monopoly position becomes and the more highly developed its division, the more clearly and certainly does it move towards a point at which its one or more monopoly rulers become the central functionaries of an apparatus composed of differentiated functions, more powerful than others, perhaps, but scarcely less dependent and fettered.

(Elias 2000, 271) 
The monopoly holders are thus increasingly transformed into conveyors or servants of an administrative apparatus with multiple functions. Those servants are certainly more influential than many other people but they are nevertheless dependent and bound by numerous contingencies, rules, laws, and functional dependence vis-à-vis the society they dominate. With the growth of the central monopoly, power slides from the private hands of the lord to numerous hands of dependent people in charge of monopoly administration. The private monopoly of a few isolated individuals becomes socialized. Controlled by whole stratums of the society, the private monopoly transforms into a public entity, the state. The monopoly is less and less arbitrarily exploited by a few individuals because the network of interdependent and differentiated functions is ruled by its own principles which progressively prevent private monopolization of the elements constituting the twin monopolies. The switch from private to public is considered by Elias as a result of an increasing social interdependency:

the power first won through the accumulation of chances in private struggles, tends ... to slip away from the monopoly rulers into the hands of the dependents as a whole, or, to begin with, to groups of dependents, such as the monopoly administration. The privately owned monopoly in the hands of a single individual or family comes under control of broader social strata, and transforms itself as the central organ of a state into a public monopoly.

(Elias 2000, 271)

So a new type of competition arises, a social competition among dependents to obtain places inside the monopoly with its own rules and system of selection: "the struggle for monopolies no longer aims at their destruction; it is a struggle for control of their yields, for the plan according to which their burdens and benefits are to be divided up, in a word, for the keys to distribution" (Elias 2000, 275; see also Bourdieu 1996). Elias considers this "unfree" regulated competition (i.e., without the force of arms) inside the monopoly as a crucial element of a "democratic regime" and he emphasizes that such a regime is in fact not the freest possible competition but "presupposes highly organized monopolies, and it can only come into being or survive ... in a very specific social structure at a very advanced stage of monopoly formation" (Elias 2000, 276). ${ }^{7}$

In the previous period, competition was free as victory went to the strongest, once the centralization process reaches its turning point competition then depends on the function and the activity that each individual is able to fulfill for the monopolist: individuals hence compete for a position in the state apparatus. From now on competition is ruled by a central administration which selects types of men and women differently from those of the previous period. The goal is no longer to abolish or to redistribute the central monopoly power but, by contrast, to reallocate charges and benefits inside the monopoly. This competition is 'pacific'; it consists in periodical 'play-offs' and supposes the creation of control procedures. All these elements of monopolization are preconditions to the contemporary 'democratic' regimes.

Be it a modern state apparatus or an absolute monarchy, the central monopoly is always weaker than the society as a whole. If the totality or a great part of the society united and rebelled against it, then the central authority would not be able to resist the pressure (Elias 2000, 353).

\footnotetext{
${ }^{7}$ For a contemporary application of 'regulated competition,' see Lee $(2012,168)$.
} 
An important condition for the reproduction of the central monopoly, not only under the form of an absolute monarchy, is hence that the acceptance or the legitimacy of the sovereign authority must be wide enough in the society. But this political element is not sufficient. Elias also emphasizes that social interests of the different parts composing the society must be sufficiently ambivalent and contradictory to ensure a maximum of strength to the central entity. The compensation or mutual neutralization of class interests inside the society plays a major role in the enforcement of the central monopoly (the well-known 'divide to rule' principle). In other words, a government structure simply based upon a narrow social basis would not be able to reproduce and last for a long period of time.

This allows us to say a few words about the Marxist conception of the state, which is so often misunderstood and caricatured by its detractors as well as by its proponents (on the Marxist conception of the state, see Barrow 2000; Lenin 1917; Herrera 2001; Poulantzas 1978). To put it briefly, for Elias the state is the expression of a class domination resulted from the longtime struggle within the warrior class for the monopoly over violence and taxation - that is, the monopoly over the domination (hence the stabilization or even the reproduction) of the society as a whole. It is thus conceivable from Elias' perspective that the state is a crucial element that contributes to the class structure formation and reproduction. ${ }^{8}$ Furthermore, if his analysis is correct then the key elements of the 'modern state' already were in place prior to the development of the capitalist system. This implies that most of the elements of the 'capitalist state' identified by, for example, Poulantzas (1978) are in fact not specific to capitalism, although the idea that an autonomous organization progressively emerges to manage the twin monopoly is very close to Poulantzas' idea of a relative autonomy of the state from the capitalist class.

Such a conception of the state is akin to a Kaleckian view of the political economy - that is, a Post Keynesian view that acknowledges the importance of class struggle, and which is also shared by Fred Lee (Lee 2011a, 18). ${ }^{9}$ From this perspective, the government is likely to implement decisions favorable to lower classes only if it does not threaten the dominant position of ruling classes. The government is also able to implement some decisions against some fractions of dominant classes in order to preserve the collective interests of the ruling classesfor example, in the face of crisis the government arbitrates in favor of dominating classes as a last resort even if the consequences are really bad for the whole society. In this regard, the state is the watchman of the class order.

In short, Elias' analysis appears as highly compatible with the Marxist conception of the state as well as a Post-Keynesian approach to the state. The socio-economic approach developed by Elias is also very close to the institutionalist tradition with its emphasis on the dynamic interactions between rules, behaviors, and mental representations. ${ }^{10}$ Thus it appears that Elias

\footnotetext{
${ }^{8}$ Of course this idea is profoundly shocking as it does not match well with the modern ideal of freedom and equality. It goes without saying that this observation is not a normative but a historical and positive statement. ${ }^{9}$ Note that Post Keynesians in general do not have a clear view of the state and class and while Kalecki had a class analysis, some later Kaleckians do not have it. For the Post Keynesian theory of the state, see Pressman (2006b).

${ }^{10}$ Neither the contribution on the institutionalist perspectives on the state by Waller (2006) nor the 'Polanyian' article by Stanfield and Stanfield (2006) in Pressman's edited book (2006a) on the theories of the state noticed the importance of Elias for their field of research.
} 
offers an important insight into the theory of the state from which an integrative and pluralistic heterodox approach could benefit greatly. Elias' analysis would become more interesting for heterodox economists if his analysis of taxes and money is considered.

\section{Taxes and money}

Before the emergence of the twin monopolies, princes and kings could not actually impose taxes directly on the population all over the Kingdom. The ability to impose taxes was based on land ownership: each lord could impose taxes on people of his own territory; in case of resistance, he could resort to his local monopoly over violence. Central taxation remained casual until the fourteenth century. Unlike regular taxation in a developed market economy, such kind of levying could be more than burdening mainly because it could be hardly predictable. As it was not a normal institution, nobody could include it in his/her calculus: trade, prices, and individual wealth could then be seriously perturbed by a tax imposed by the central authority. This is all the more true that such a kind of central taxation was often required in money: less advanced countries, where monetary exchange was not well developed, could have considerable problems meeting the central demand, which could hence turn into a tragedy.

During the middle ages, government expenditures were supposed to be financed only through the revenue of the dynastic possessions of the central lord (the 'ordinary'). Even when the king started to become more than a big warrior among other big warriors from the end of the twelfth century onwards, he could not afford to impose taxes as he wished on his whole sphere of influence. He had to gather the representatives of the three orders (Nobility, Church, and Third Estate) into States-General (Etats Généraux, or simply the 'States'). The king had to justify the reasons of an extraordinary tax raising (the 'extraordinary' also called the 'helps' or aides) and to be authorized by the States to do so. With the Hundred Years' War (1337-1453), the need for money to finance the war became permanent which forced the States to be in session more and more often. In 1362, John the Good was taken as a captive to England. The necessity to pay a huge ransom compelled the States to plan annual taxes in the whole Kingdom over 20 years, which greatly accelerated the extension process of levying taxes regularly at the monopoly level. In 1436, King Charles VII was able to impose taxes without the States convening. This indicates that the king already gained sufficient social power. From then on, the king was able to raise funds through taxation on the whole Kingdom territory, beyond his own dynastic domain, without resorting to any formal authorization (Elias 2000, 348 and passim). Through wars, the link between monopoly over violence and monopoly over taxes is particularly obvious: the need to spend money for war requires more and more taxes beyond the individual domain of the king which reinforces in turn the army and the police of the central power. Just as efficiency requires the command of war to be centralized, the war resources have become also more and more centralized.

The cities developed against local lords and got early special protection from the central power. Normally, just like any feudal lord, city bourgeois should provide military units to the king if an enemy was to threaten the Kingdom. Very early, instead of sending their sons to be killed for the homeland, bourgeois of cities started to give money to the central power. On the one hand, military service could be bought. This kind of monetary transaction helped develop 
the double monopoly and extend the tax systems initially created by independent cities. This replacement of military service by monetary tax also shows the profound and explicit link which existed between both monopolies six or seven centuries ago. On the other hand, the central power found it useful to collect money through the tax system because it was easy to hire mercenaries among poor people and to command armament and war equipment directly from manufacturers at a massive scale. Monetary-fiscal resources were preferred to payment in kind since the latter gave less freedom to the central monopoly. For this reason and also because they quickly understood that they could practice seigniorage if they could impose their own money, lords started to demand taxes in money. This contributed greatly to develop monetary exchanges. Instead of remaining more or less self-sufficient and to sell only the surplus necessary to get enough money for the provision of commodities produced elsewhere, people were enforced to obtain more money order to be able to pay their taxes and hence to sell more. As more money was flowing into the Treasury chests, more money was also used in the whole economy to buy commodities. Here again, monetary exchanges, trade, and markets were greatly stimulated, if not created, by the development of a central monopoly and its demand for taxes in money. Money taxes can therefore be said to have contributed to the institutionalization and stimulation of money market exchanges. Obviously, this conception of money is very close to the chartalist tradition initiated notably by Georg Friedrich Knapp who may have influenced Elias during his training in Germany. This state money tradition continues in Post Keynesian economics through John Maynard Keynes and his followers, and Fred Lee advocates this view of money in his integrative approach to the economy as a whole (Lee 2011c, 1293). ${ }^{11}$

\section{Power centralization and economic development}

Until the rise of centralized taxes paid in money, the central power had to reward its main partisans and the closest members of the royal family with fractions of its domain. Indeed, the lord or the king used to give his sons and daughters castles, counties, or duchies because they had to live in accordance with their rank and hence maintain the prestige of their royal origin. This system of appanage was thus a counter-movement to monopolization. It was a factor of decentralization, fragmentation, and disintegration of the family domain, though the basis of the monopoly power until the absolutist period. With the huge increase in monetary resources that occurred with systematic money taxation, this counter-movement disappeared because the central power could then distribute prebends in money. This further rendered servants more dependent and devoted to the Prince that they did not possess their own piece of land. On this aspect again, demanding taxes in money considerably contributed to the reinforcement of the central monopoly because (i) the royal domain ceased to be divided and (ii) the persons integrated into the central administration became monetary dependent and hence more loyal. The necessity to develop an administration system for the twin monopoly thus stimulated the payment of taxes in money and the development of monetary exchanges in turn facilitated the development of the administrative structure.

\footnotetext{
${ }^{11}$ See for instance the contribution of Wray (1998) for a recent chartalist and historical approach of money.
} 
Lastly, Elias establishes an interesting link between the level of development of the economy and the form of the state. He distinguishes a "barter economy" from a "money economy" (Elias 2000, 205-206). A barter economy is not an imaginary economy without money that is usually presented to students to tell the tale of the origins of money as a commodity. For Elias, there is money even in a barter economy and such an economy refers actually

to a society in which the transfer of goods from the person who gets them from the soil or nature to the person who uses them takes place directly, that is without intermediaries, and where they are worked up at the house of one or the other, which may well be the same.

(Elias 2000, 207)

He considers that "as long as barter relationships predominated in society, the formation of tightly centralized bureaucracy and a stable apparatus of government working primarily with peaceful means and directed constantly from the centre, was scarcely possible" (Elias 2000, 205). In other words, the fragmentation and the predominance of short distance domestic exchanges prevent the centralization process of the twin monopoly from occurring. With the development of a money economy the feudalization of states (centrifugal forces) can step back. It is easy to imagine the relationship going from the development of the money economy to the development of the modern state: the diffusion of money allows the diffusion of money taxes, which in turn reinforces the centralization process. According to this view, the development of the modern state is subject to the rise of private market exchanges. Here the state remains as a result of the economy which appears as a distinct and autonomous force but this is not exactly the idea developed by Elias in his book. For him, the state is actually embedded in the economy. Both the state and the economy co-evolve because the development of the state itself has an influence on the development of the economy: the relation goes both ways. Not only does the state need the economy for tax raising, but the economy also cannot expand before the state has reached a certain degree of development:

economic struggles .... presuppose the secure existence of certain very advanced monopolies. Without the monopoly organization of physical violence and taxation ... the restriction of this struggle for 'economic' advantages to the exertion of 'economic' power, and the maintenance of its basic rules, would be impossible over any length of time even within individual states. In other words, the economic struggles and monopolies of modern times occupy a particular position within a larger historical context.

(Elias 2000, 277)

Besides, Elias insists on the idea that before the advent of centralization in the form of a genuine state apparatus each lord used to consider his estates as his private property like a "small family enterprise" (Elias 2000, 291), which gave them an autarkic character. Each warrior house was hence induced to focus on the consolidation of its control over its possessions and its internal development to increase its revenues, which must have had an impact on the development of activities and of internal connections and transports. He considers that the merging of different possessions even stimulated economic integration:

their union under one and the same house and partly under the same administration, did remove a whole series of obstacles in the way of fuller integration. It corresponded to the 
tendency towards an extension of trade relations, the intensification of links beyond the local level, which was already discernible in small parts of the urban population.

(Elias 2000, 287)

And he adds a few lines further that, under the protection of the princes' houses, towns and trade flourished and profited from the concentration of power which in turn relied on the concentration of human and financial resources offered by urban strata and growing commercialization.

This kind of positive feedback between the development of the money economy and the centralization process logically implies the idea of a cumulative causation. But this framework can also be pushed a step further and viewed as a macroeconomic understanding, and closing off, of the monetization of taxes in relation with the development of money economy. As for taxes, not only is the state able to levy money taxes more easily when monetary exchanges develop but the fact that taxes are no longer payable in kind also stimulates the economy because it induces people to bring to the market more commodities in order to obtain more money inter alia to pay taxes with money. As for 'public' spending, the central power is now able to give a monetary revenue to the 'civil' servants, instead of endowing them with a piece of land; this new class of money earners has hence to spend at least a part of its income for its everyday life which creates a new demand for consumption goods. The same reasoning applies to direct spending by the central power, for instance, for the equipment of its armies. Now that it receives more taxes in the state money form, the government is henceforth able to buy more supplies, equipments, arms, horses, manufactured goods from the private sector which stimulates economic activities and allows suppliers to get the money they need to pay their taxes. Thus it appears more clearly how the state develops through the monetization of taxes and state spending is a vector of economic development which steers both supply and demand on markets. For this reason an economic theory that considers the economy and the state separately is fallacious. The state and the economy appear as profoundly interlocked to each other. The reader must have noticed that the present argument of the embeddedness of the state in the economy is not based upon the classical Smithian contention that the state provides pacification (defense, justice) services or 'public goods' which are supposed to have a positive effect on private business. Of course, these elements presented by Adam Smith in the first chapter of the fifth book of the Wealth of Nations are not contradictory to Elias' viewpoint but, merely, The Civilizing Process goes much further in the understanding of, among other things, the state embeddedness.

\section{Conclusion}

This chapter has emphasized that Norbert Elias' view of the economic development and socio-economic relations on the emergence of the state is very close to Fred Lee's conception of heterodoxy. The second section has shown that for Elias the competition for power and land leads necessarily to monopoly. He considers that this type of competition process dismisses any notion of competitive equilibrium and applies to modern economic activities and not only to middle ages' political and military struggles. The third section highlighted the double nature of the monopoly power that forms the very core of the state: monopoly over 
violence and over taxes. The fourth section developed the idea that administration and bureaucracy are unavoidable outcomes of the centralization process. The fifth section on taxes and money showed that, according to Elias, the development of the state and monetary exchanges are stimulating each other. This state money approach is also shared by Fred Lee in his integrative model of the economy as a whole. The sixth section exposed that the development of the economy has to be understood as the development of the state as well and vice versa: one is impossible without the other. Fred Lee addressed this view in his last lecture in April 2014 that building a macro model without the state amounts to writing fairy tales (Lee 2014).

\section{Acknowledgments}

The author is grateful to Tae-Hee Jo, Zdravka Todorova, and an anonymous referee for most helpful comments and suggestions.

\section{References}

Barrow, C. W. 2000. "The Marx Problem in Marxian State Theory.” Science \& Society 64 (1): 87-118.

Bourdieu, P. 1996. The State Nobility: Elite Schools in the Field of Power. Cambridge: Polity Press.

Bourdieu, P. 2012. Sur l'État, Cours au Collège de France (1989-1992). Paris: Raisons d'Agir/Seuil.

Descimon, R. and A. Guéry. 2000. "Un État des Temps Modernes?" in Seuil Histoire de la France. La longue durée de l'État, edited by Jacques LeGoff, vol. 1, 209-503. Paris: Éditions du Seuil.

Elias, N. 2000. The Civilizing Process. Oxford: Blackwell Publishing (originally published as Über den Prozess der Zivilisation, as two separate volumes in 1939 by Haus zum Falken; English translation: The History of Manners, 1978, Basil Blackwell and State Formation and Civilization, 1982, Basil Blackwell).

Herrera, R. 2001. "Brève introduction à la théorie de l'État chez Marx et Engels." Cahiers de la MSE, série rouge, $\mathrm{n}^{\circ} \mathrm{R} 01001$.

Jo, T.-H. 2011. "Social Provisioning Process and Socio-Economic Modeling." American Journal of Economics and Sociology 70 (5): 1094-1116.

Jo, T.-H., ed. 2013. Heterodox Economics Directory, 5th ed. Accessed December 19, 2014. http://heterodoxnews.com/directory/hed5.pdf.

Lee, F. S. 2008. "Heterodox Economics." In The New Palgrave Dictionary of Economics, 2nd ed., edited by S. N. Durlauf and L. E. Blume. London: Palgrave Macmillan.

Lee, F. S. 2009. A History of Heterodox Economics. London: Routledge.

Lee, F. S. 2011a. "Heterodox Microeconomics and the Foundation of Heterodox Macroeconomics." Economia Informa 367: 6-20.

Lee, F. S. 2011b. "Heterodox Surplus Approach: Production, Prices, and Value Theory." MPRA Working Paper 31824. Accessed December 19, 2014. http://mpra.ub.unimuenchen.de/31824. 
Lee, F. S. 2011c. "Modeling the Economy as a Whole: An Integrative Approach." American Journal of Economics and Sociology 70 (5): 1282-1314.

Lee, F. S. 2012. "Competition, Going Enterprise, and Economic Activity." In Alternative Theories of Competition: Challenges to the Orthodoxy, edited by J. K. Moudud, C. Bina, and P. L. Mason, 160-173. London: Routledge.

Lee, F. S. 2014. "The Role of Microeconomics in Heterodox Economics: A View of a Heterodox Micro Theorist." Unpublished transcript of Fred Lee's last lecture at the University of Missouri-Kansas City, April 24, 2014. The video of this lecture is available at http://heterodoxnews.com/leefs/fred-lee-lecture-at-umkc.

Lenin, V. 1917. The State and Revolution. Accessed December 19, 2014. www.marxists. org/archive/lenin/works/1917/staterev/index.htm.

Poulantzas, N. 1978. Political Power and Social Classes. London: Verso.

Pressman, S., ed. 2006a. Alternative Theories of the State. New York: Palgrave Macmillan.

Pressman, S. 2006b. "A Post Keynesian Theory of the State." In Alternative Theories of the State, edited by S. Pressman, 113-138. New York: Palgrave Macmillan.

Stanfield, J. R. and J. B. Stanfield. 2006. "The Protective Response and the Evolution of the Capitalist State." In Alternative Theories of the State, edited by S. Pressman, 34-63. New York: Palgrave Macmillan.

Todorova, Z. 2013. "Connecting Social Provisioning and Functional Finance in a PostKeynesian-Institutional Analysis of the Public Sector." European Journal of Economics and Economic Policies: Intervention 10 (1): 61-75.

Waller, W. 2006. "The Pragmatic State: Institutionalist Perspectives on the State." In Alternative Theories of the State, edited by Steven Pressman, 13-34. New York: Palgrave Macmillan.

Weber, M. 1968. Economy and Society. New York: Bedminster Press.

Wray, L. R. 1998. Understanding Modern Money. Northampton, MA: Edward Elgar. 